\title{
Expression of Anaplastic Lymphoma Kinase in Astrocytic Tumors (Histopathological and Immunohistochemical Study)
}

\author{
Abdul Hakeem Ibrahim Abdul Hakeem, Randa Said Taha Khaled*, Mohamed Sherif Ismail \\ Department of Pathology, Faculty of Medicine, Cairo University, Giza, Egypt
}

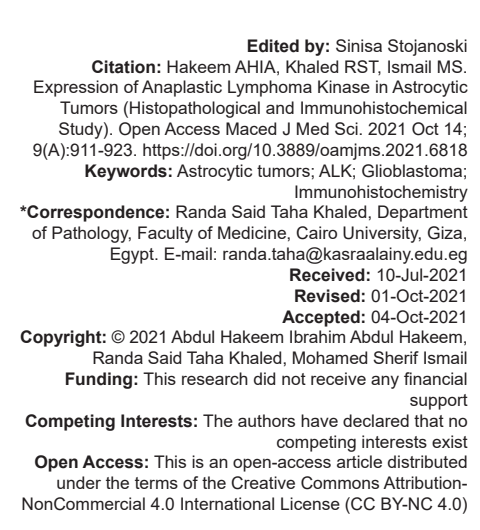

Introduction

Astrocytic tumors are the most common primary tumor of the brain [1]. The World Health Organization (WHO) classification system divides them into four grades according to their biological behavior; the least aggressive are WHO grade I tumors and the most aggressive represent WHO grade IV tumors [2]. The recent update in WHO classification of astrocytic tumors was based on incorporating molecular parameters besides histopathologic examination [3]. Glioblastoma (GBM) is the most lethal and most common primary malignant brain tumor [4]. The exact cause of astrocytic tumors was unknown, but cell phone use was a recent potential risk factor for the development of many gliomas [5].

Astrocytic tumors are more common with increasing age, male gender and white race [6]. Lowgrade astrocytic tumors account for $30 \%$ of all astrocytic tumors [7]. High-grade astrocytic tumors are very common among the elderly [8]. Astrocytic tumors were the most commonly diagnosed central nervous system (CNS) tumor in the Delta region in Egypt followed by meningioma [9]. In Egypt, astrocytomas account for about $54.85 \%$ of CNS tumors diagnosed at $\mathrm{NCl}$, Cairo University during the period 2000-2011 [10].

The WHO scheme is based on the appearance of certain characteristics: atypia, cellularity, mitoses, endothelial proliferation, and necrosis. These features reflect the malignant potential of the tumor in terms of invasion and growth rate. Astrocytic tumors have four WHO grades as follow: Astrocytic tumors without any of these features are classified as WHO grade I. This includes pilocytic astrocytoma and subependymal giant cell astrocytoma. Astrocytictumors with cytological atypia alone are considered WHO grade II. This will include diffuse astrocytoma, pleomorphic xanthoastrocytoma, and pilomyxoid astrocytoma. Astrocytic tumors with anaplasia and high mitotic activity in addition to cytological atypia are considered WHO grade III. This will include anaplastic astrocytomas and anaplastic pleomorphic xanthoastrocytoma. Astrocytic tumors exhibit marked anaplasia, high mitotic activity, atypical mitoses as well as microvascular proliferation and/or necrosis are considered WHO grade IV, representing the most aggressive type, GBM [2]. 2016 WHO update contains numerous differences from the 2007 CNS 
WHO classification. The current update breaks with the century-old principle of diagnosis based entirely on microscopy by incorporating molecular parameters into the classification of CNS tumor entities [11].

The biopsy is the gold standard in the diagnosis of astrocytic tumors [12]. Treatment modalities include surgery, followed by observation, and chemotherapy or radiotherapy, depending on histological characteristics and extent of tumor resection [13], [14]. Therapeutic resistance is due to poor drug delivery [15]. The majority of astrocytic tumors will recur after surgery [16] due to single tumor cell infiltration leading to incomplete surgical removal and high recurrence rate [17].

The prognosis for astrocytic tumors is highly dependent on their WHO grade, being extremely poor for WHO grade IV tumor while there is long-term survival for WHO grade I tumor [18] and less than 1 year for patients with GBM [19]. Age is a significant prognostic factor for low-grade astrocytoma as survival benefits may be confined to those under age 50 years [20].

Anaplastic lymphoma kinase (ALK) gene is located at the short arm of chromosome 2 that encodes ALK receptor tyrosine kinase [21]. ALK plays an important in cell proliferation and cell differentiation [22]. Many translocations involving ALK gene have been seen in cases of anaplastic large cell lymphoma [23]. In cases of non-small-cell lung cancer, there is a fusion of ALK gene to EML4 gene [24].

Activated ALK causes increased VEGF secretion in anaplastic large-cell lymphoma [25]. Recent report describes an alternative transcription initiation site leading to the detection of an oncogenic ALK isoform in $11 \%$ of melanomas [26]. Mucosal melanoma which expresses a novel EML4-ALK fusion is highly sensitive to ALK inhibitors [27]. Recently, high-grade glioma of infancy revealed a novel PPP1CB-ALK fusion protein [28]. Some hypothesized that ALK signaling may contribute to tumor growth through hypoxia-independent neovascularization in GB [29], [30]. ALK-positive cells are linked with neovascularization features including vascular co-option and vascular mimicry in GB [31]. Overexpression of ALK induces an enhancement of the HIF-1 $\alpha /$ VEGF-A-axis [32].

ALK has a role in embryonic CNS development. ALK receptor is thought to contribute to nervous system function, repair, and metabolic homeostasis. ALK receptor activity in cancer can be mediated by amplification, overexpression, ligand binding, mutations in the intracellular domain of the receptor and by the activity of the receptor tyrosine phosphatase. Overexpression of ALK, its smaller homolog leukocyte tyrosine kinase,and the ligands PTN and MK in cancer tissues from patients correlate significantly with worse outcomes of the tumor [33].

ALK rearrangements have been reported in many brain tumors [34]. ALK and its ligand, pleiotrophin, are highly expressed during embryonic brain development and in high-grade brain tumors such as GBM compared to normal brain tissue [35], [36]. ALK and CMET protein expression were seen in a significant number of GBM samples, with $55 \%$ having concurrent ALK gene amplification along with cMET overexpression and these data suggest a role for cMET and/or ALK in the pathogenesis of GBM [37]. There is promising potential for new chemotherapeutics targeting ALK and CMET to improve the prognosis of GBM [38].

\section{Materials and Methods}

This retrospective study was carried out on 60 cases of randomly chosen formalin-fixed paraffinembedded tissue blocks of patients diagnosed with astrocytic tumors from the archives of the Pathology department of Cairo University of Medicine from the period from January 2015 till January 2019. We included only astrocytic tumors with adequate biopsies and excluded those with extensive hemorrhage and necrosis. Clinicopathological data of all cases were recorded from the patient records and tabulated. Ethical clearance was obtained by the institutional review board before the study.

Each paraffin block was cut by rotator microtome at $5 \mu$ thick sections which were then mounted on glass slides to be stained by hematoxylin and eosin for histopathological re-evaluation by two pathologists and on charged glass slides for immunostaining process.

The slides were deparaffinized in xylene. Then, they were treated for antigen retrieval (using a microwave oven for $30 \mathrm{~min}$ ) an automated Omnis DAKO immunostainer at a high $\mathrm{pH}$ of 8 . After this, the sections were treated with antibodies using avidinbiotin-peroxidase 3\% (Thermo Scientific) for $30 \mathrm{~min}$. Diaminobenzidine tetrahydrochloride was used as a substrate and chromogen. Hematoxylin (Biogenex) was used as a counterstain. The primary antibody was a mouse monoclonal antibody for ALK (clone 5A4, Newcastle, United Kingdom) was used at a dilution of 1:30 and incubated at $42^{\circ} \mathrm{C}$ for $2 \mathrm{~h}$.

The WHO scheme is based on the appearance of certain characteristics: atypia, mitoses, endothelial proliferation, and necrosis. These features reflect the malignant potential of the tumor in terms of invasion and growth rate. Astrocytic tumors have four WHO grades as follows; Astrocytic tumors without any of these features are classified as WHO grade I. Astrocytic tumors with cytological atypia alone are considered WHO grade II. Astrocytic tumors with anaplasia and high mitotic activity in addition to cytological atypia are considered WHO grade III. Astrocytic tumors exhibit marked anaplasia, high mitotic activity, atypical mitoses as well as microvascular proliferation and/or necrosis are considered WHO grade IV representing the most aggressive type, GBM [2]. 
Tumor tissue sections were examined and scored under Leica DM500 microscope at low power than high power magnification by two independent pathologists who were not informed of the histological diagnosis. Assessment of ALK expression in the tumor cells was designated as brownish cytoplasmic staining in more than $10 \%$ of tumor cells (threshold point of positivity). The intensity of cytoplasmic staining was subcategorized into: Negative; absence of cytoplasmic staining, weak; faint cytoplasmic staining, moderate intensity; moderate cytoplasmic staining and strong intensity; intense cytoplasmic staining. Five categories on the basis of the proportion of immunopositive cells, as follows: Score 0; all tumor cells are negative, Score $1 ;<25 \%$ of tumor cells are positive, Score $2 ; 25 \%-$ $<50 \%$ of tumor cells are positive, Score 3; $50 \%-75 \%$ of tumor cells are positive, Score $4 ;>75 \%$ of tumor cells are positive [30].

The positive control was from CD30 positive anaplastic large cell lymphoma (ALK positive). ALK positivity in the background stroma served as a positive internal control. The results of ALK immunostaining in tumor cells were correlated with multiple prognostic factors including (age, sex, site, side, tumor recurrence, clinical presentation, and $\mathrm{WHO}$ grade of astrocytic tumor).

Microsoft excel 2010 was used for data entry and the statistical package for social science (SPSS version 21) was used for data analysis. Simple descriptive statistics (arithmetic mean and standard deviation) used for the summary of quantitative data and frequencies used for qualitative data. The bivariate relationship was displayed in cross-tabulations and comparison of proportions that were performed using the Chi-square test. The T-independent test was also used to compare normally distributed quantitative data. The Chi-square test was used to assess differences between qualitative variables, while t-test and analysis of variance tests were used for quantitative variables. The significance of the results was assessed by determining probability factor "p-value". $p<0.05$ was considered statistically significant.

All slides were screened on Leica DM500 microscope and all photos were imaged by $\mathrm{HD}$ digital microscope camera, named Leica ICC50 HD, connected to the same microscope.

\section{Results}

This study included 60 cases of astrocytic tumors, in which the ages of the patients ranged 13 years to 72 years with mean age 43.1 ( \pm 15.63 years) (Figure 1). Statistical analysis showed that the peak incidence of astrocytic tumors was found in the seventh decade followed by fifth decade of life. As regards to the

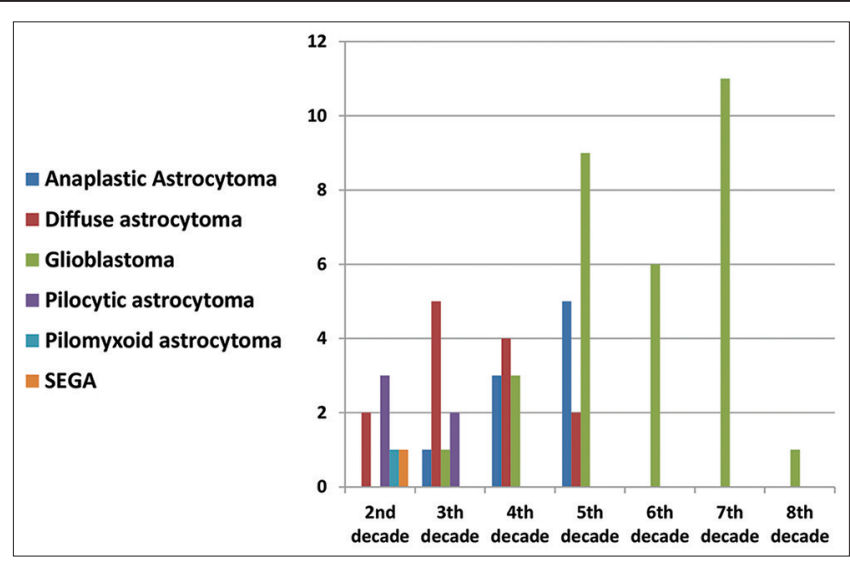

Figure 1: Age distribution among studied cases

gender, male preponderance was noted; as we have 40 males ( $66.7 \%$ of studied cases) and 20 females (33.3\% of studied cases) with a female to male ratio of $1: 2$.

As regards the histological diagnoses as well as WHO grades (Figure 2) of astrocytic tumors among the studied cases; $6(10 \%)$ cases were classified as WHO grade I astrocytic tumors including five cases of pilocytic astrocytoma and one case of SEGA. Fourteen $(23.3 \%)$ cases were classified as WHO grade II astrocytic tumors including $13(21.7 \%)$ cases of diffuse astrocytoma as well as one (1.6\%) case of pilomyxoid astrocytoma. Nine (15\%) cases were classified as anaplastic astrocytoma, WHO grade III. Thirty-one $(51.7 \%)$ cases were classified as GBM, WHO grade IV.

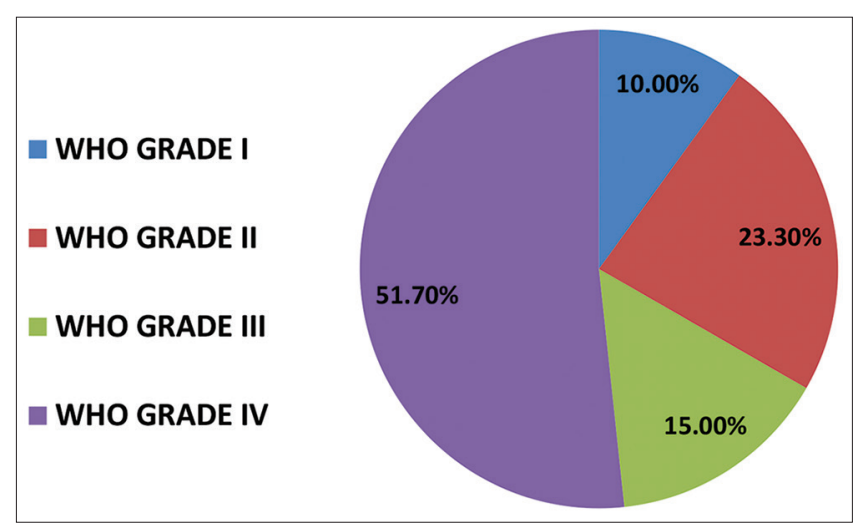

Figure 2: World Health Organization grade distribution among studied cases

Astrocytic tumors showed preference for cerebral hemisphere in our study as 48 (80\%) cases showed a cerebral hemisphere location (Figure 3).

We found a left sided preponderance in our study, as $34(56.7 \%)$ cases were left sided, 20 (33.3\%) cases were right sided and $6(10 \%)$ cases were midline in location. As regards the clinical presentation among the studied cases; $25(41.7 \%)$ cases presented by seizures, $21(35 \%)$ cases presented by headache, $14(23.3 \%)$ cases are presented by hemiparesis.

ALK expression was not established in $57(95 \%)$ cases which showed a negative intensity, 


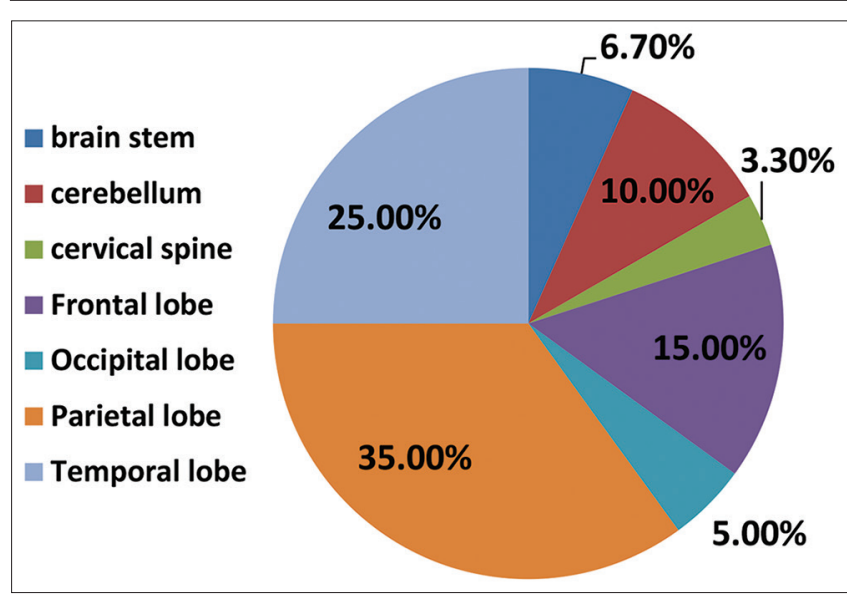

Figure 3: Anatomical distribution among studied cases

(score 0) while three cases $(5 \%)$ cases had strong cytoplasmic intensity; two cases were score 4 and the remaining case a score of 1 (Figure 4). The two strongly positive cases were GBM, WHO grade IV, gliosarcoma variant and both cases were left sided; one located in the occipital lobe while the other located in the temporal lobe. The remaining strongly ALK-positive case was score 1 detected in a case of right-sided anaplastic astrocytoma, WHO grade III, located in the parietal lobe. Correlation between ALK expression and WHO grade as well as tumor laterality were non significant ( $p=0.366, p=0.344)$, respectively. In addition to the remaining correlations between age, gender, and tumor location also displayed lack of statistical significance.

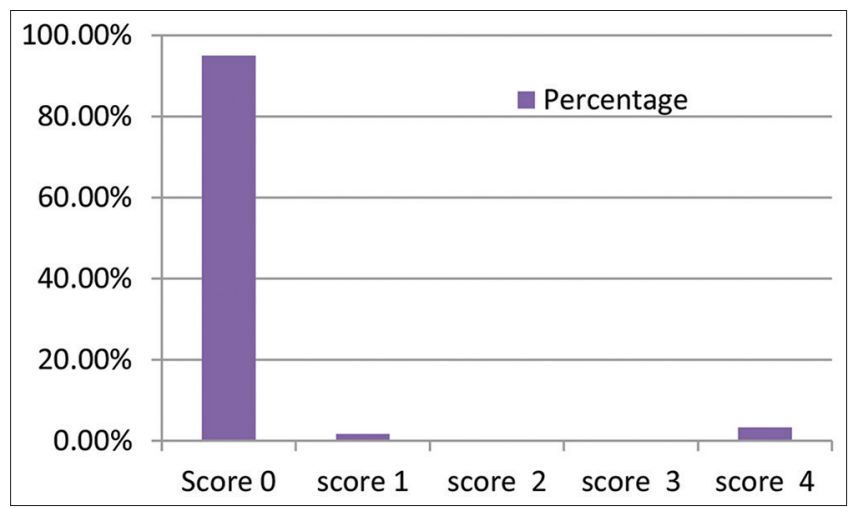

Figure 4: ALK expression among studied cases

On the other hand, there was a statistically significant correlation seen between age of patients and gender among the study group $(p=0.001)$ with females tending to present with astrocytic tumors at an older age than males. With a similar pattern, the correlation between the age of patients and $\mathrm{WHO}$ grade of the astrocytic tumors among the study group was statistically significant $(p=0.001)$ implying an increase in WHO grade with older age groups. Another correlation between the gender of patients and tumor recurrence was seen $(p=$ 0.001), implying a more tumor recurrence among males.

The gender of the patients showed multiple significant correlations including WHO grade of the tumors, clinical presentation, and tumor location and recurrence.
WHO grade I tumors were commonly located in the cerebellum while WHO grade II tumors as well as WHO grade III tumors were commonly located in the parietal lobe. The WHO grade IV tumors were commonly located in the parieto-temporal region. The location of the tumor and the WHO grade showed statistically significant correlation ( $p=0.001)$.

In addition, the tumor location and clinical presentation (Figure 5) was statistically significant $(p=0.006)$. Tumors that affect the brain stem and cervical spine are presented by hemiparesis. Tumors that are affect the cerebral hemisphere are commonly presenting by seizures. Cerebellar tumors are commonly presented by headaches. Regarding the WHO grade of the tumors, the higher the $\mathrm{WHO}$ grade, the higher the possibility of tumor recurrence $(p=0.001)$. The relationship between clinical presentation and $\mathrm{WHO}$ grade of the astrocytic tumors showed a significant finding $(p=0.001)$ implying that the higher the grade, the more frequent the clinical presentation.

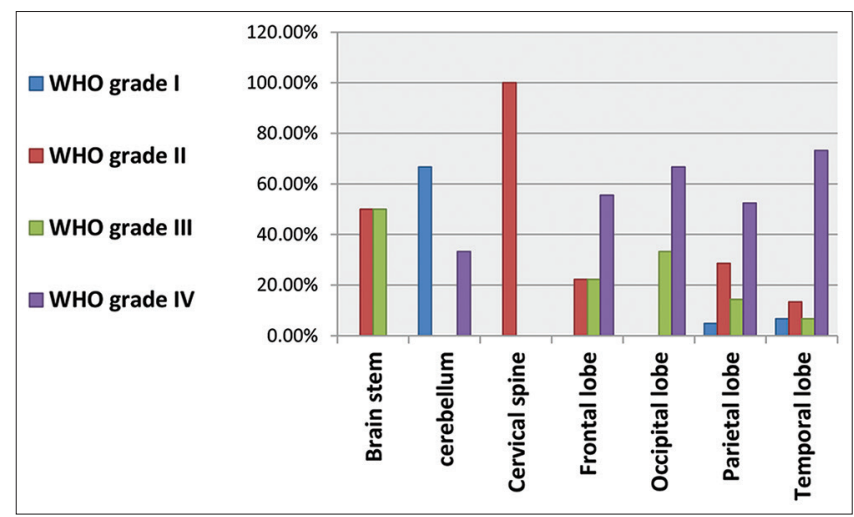

Figure 5: World Health Organization grade distribution with correlation to anatomical site among studied cases

Histopathological and findngs of different cases of astrocytic tumors are presented on Figures 6-20.

\section{Discussion}

Astrocytic tumors are the most frequent primary brain tumors. They originate in a particular type of glial cells known as astrocytes. GBM is a highly aggressive astrocytic tumor and is reported to be the most common and the most lethal primary brain tumor [39]. ALK contributes to gliomagenesis via multiple mechanisms including growth stimulation, anti-apoptotic pathways, self-renewal of glioma stem cells and angiogenesis [40].

As regards the expression of the ALK among our study group; we noticed that ALK was strongly expressed in High-grade astrocytic tumors especially gliosarcoma cases. In our study we had 57 (95\%) cases having negative staining, score 0 while three $(5 \%)$ cases had strong cytoplasmic intensity; two cases were score 4 and one case was score 1. 
Karagkounis et al. found that ALK overexpression in up to $70 \%$ of GBM without a significant correlation with any underlying ALK gene amplification and they used different immunohistochemical techniques by using two anti-ALK antibodies [41].

In our study, we find the two strongly positive cases, score 4 were left-sided GBM, WHO grade IV, gliosarcoma variant; one located in the occipital lobe while the other located in the temporal lobe. The remaining strongly ALK-positive case was score 1 detected in a case of right-sided anaplastic astrocytoma, WHO grade III, located in the parietal lobe. Chiba et al., 2017 showed ALK immunopositivity in nine of 51 WHO grade II tumors, five of 29 WHO grade III tumors, and $29(49.2 \%)$ of 52 GBM cases with a higher immunohistochemical scores in GBM as compared to those of lower grade astrocytic tumors [30]. It may be due to the larger sample size as we used a similar antiALK antibody (5A4). Genetic or environmental factors may play role in such differences.

In our study group, two females showed positive ALK expression while negative ALK expression was demonstrated in 18 females. One male showed positive ALK expression while negative ALK expression were demonstrated in 39 males. Two positive cases presented with hemiparesis while the third positive case presented with seizures. Correlation between ALK expression and age of patients was statistically nonsignificant with mean age 42.8 ( \pm 15.9 years) for score 0 cases while mean age was 41 for the score 1 case as well as mean age was 52.5 for score 4 cases.

There is no statistically significant correlation between ALK expression on one hand and other variables on the other hand including; age, gender, clinical presentation, location, laterality, recurrence and the WHO grade of the astrocytic tumors $(p=0.285$, $0.285,0.289,0.750,0.344,0.723,0.366$, respectively). The high number of negative cases for ALK in our study group suggests that ALK expression is not associated with a prognostic significance toward astrocytic tumors whatever its grade similar.

To the results stated by Karagkounis et al., 2017 who stated that despite of being highly expressed ALK in the GBM cases, ALK overexpression did not show a correlation with prognosis in their study [41]. Recently and on a molecular base ALK variation was an independent indicator of poor prognosis in gliomas and IDH-WT-GBM evidenced by the presence of only germline ALK variants in 12 out of 99 cases $(12.12 \%)$ [42]. These finding is a possible important clue to our immunohistochemical results in our study in high-grade astrocytic tumors, especially in GB cases.

Our results are close to Junca et al., 2017 who stated that no significant dysregulation of ROS1 or ALK in GSCs and the associated tumors. Neither amplification nor polysomy of ALK was observed in GSC as well as no ALK mutation was found by Sanger's direct sequencing [43]. This is recently encouraged by Niklas et al., 2019 who stated that the majority of GBM cases showed no copy number aberrations of $A L K$ gene [44]. However Chmielecki et al., 2017 stated that despite negative immunohistochemistry, novel genetic fusions can be detected through molecular studies in some astrocytic tumors like PPP1CB-ALK fusion [45].

The age of patients in our study ranged from 13 years to 72 years with mean age 43.1 ( \pm 15.63 years) which was near what was reported by Parvin and Fatemeh, 2019 whose mean age was 46.53 ( \pm 1.81 years) [46] and away from what reported by Chiba et al., 2017 who find the mean age of the patients in their study was 54.3 years [30].

The mean age of the patients with WHO grade IV tumors, GBM, ranged from 30 years to 72 years in our study with mean age of 54 ( \pm 11.1 years) close to that stated by Karagkounis et al., 2017 who found the mean age among GBM cases was $59.5 \pm 12.4$ years [41]. Statistical analysis showed that the peak incidence of astrocytic tumors was found in the seventh decade followed by the fifth decade of life that is reported by Raverto et al., 2010 who stated that astrocytic tumors, especially the most common and most aggressive tumor termed GBM, can be developed at any age, but its incidence rate is reported to be the highest at 45-75 years of age [47] while Zalata et al., 2011 showed that the sixth decade followed by the fifth decade are the peak incidence for astrocytic tumors in Delta in Egypt and this difference may be due to the large sample size (452 cases) [9].

We found a male preponderance in our study with forty cases were males $(66.7 \%$ of studied cases) as well as twenty females (33.3\% of studied cases) matching the results of Karagkounis et al., 2017 who found $33 / 51$ cases were males $(65 \%$ of studied cases) [41]. Also Zalata et al., 2011 found a male preponderance (about $63 \%$ of studied cases) [9].

Astrocytic tumors showed a preference for the cerebral hemisphere in our study as 48 (80\%) cases showed a cerebral hemisphere location, while 12 (20\%) cases were located outside the cerebral hemisphere. The astrocytic tumors located within the cerebral hemisphere among our studied cases as follows; $21(35 \%)$ cases located in the parietal lobe representing the most common location for astrocytic tumors, $15(25 \%)$ cases located in the temporal lobe, $9(15 \%)$ cases in the frontal lobe as well as $3(5 \%)$ cases affect occipital lobe. However, Jonas et al., 2018 reported that the commonest location for the astrocytic tumor was the frontal lobe $(29.4 \%)$ and this difference may be due to the presence of many cases had multifocal locations in their study (31.4\%) [48].

Frontal lobes were most frequently involved (more than $50 \%$ of all cerebral sites) followed by the tempro-parietal region as stated by Zalata et al., 2011 and Karagkounis et al., 2017 [9], [41]. Furthermore, 


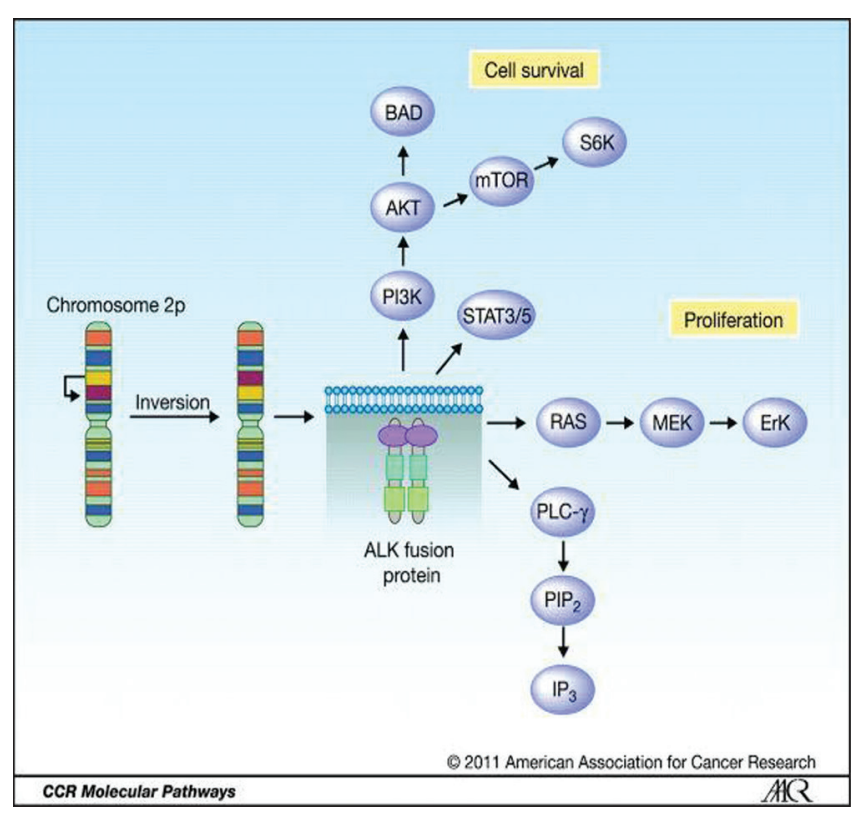

Figure 6: Role of the anaplastic lymphoma kinase as oncogene (American Association for Cancer Research, 2011)

frontal lobe is the commonest location for astrocytic tumors representing ( $37 \%$ of cases) as stated by Ze-Lin Sun et al., 2015 possibly due to its sample concentrated on WHO grade II and III tumors [49]. The temporal lobe is the second most common location in their study, as we found in our study, representing $27 \%$ of cases which is very close to our results ( $25 \%$ of cases). Karagkounis et al., 2017 also found temporal lobe location was the second most common location for astrocytic tumors in $37 \%$ of cases [41].

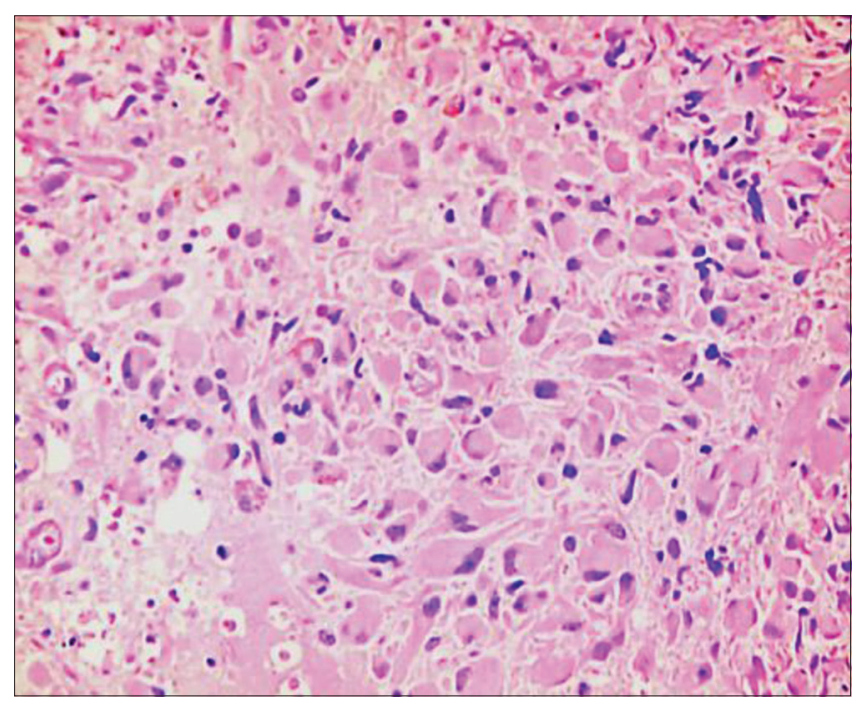

Figure 7: A case of SEGA, World Health Organization grade I, formed of large cells exhibiting abundant eosinophilic cytoplasm and eccentric nuclei with scaterred spindle cells (hematoxylin and eosin $\times 400$ )

The astrocytic tumors that are located outside the cerebral hemisphere including six $(10 \%)$ cases located in cerebellum, four $(6.7 \%)$ cases located in brain stem and two $(3.3 \%)$ cases located in cervical spine. Zalata et al., 2011 showed $78.8 \%$ of astrocytic tumors having cerebral hemisphere location while $9 \%$ having cerebellar

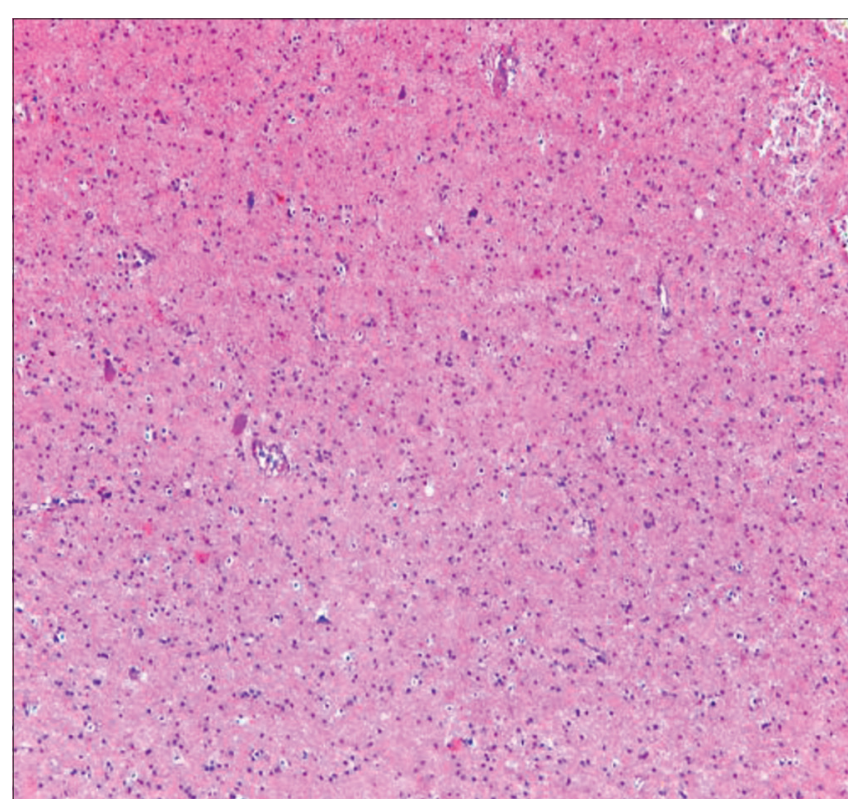

Figure 8: A case of diffuse fibrillary astrocytoma, World Health Organization grade II, showing mild cellularity with fibrillary background (hematoxylin and eosin $\times 100$ )

location as well as $5.5 \%$ having brain stem location and $3 \%$ having the spinal location in Delta in Egypt [9] which very close to our study results and this possibly due to similar racial, socioeconomic and geographic factors.

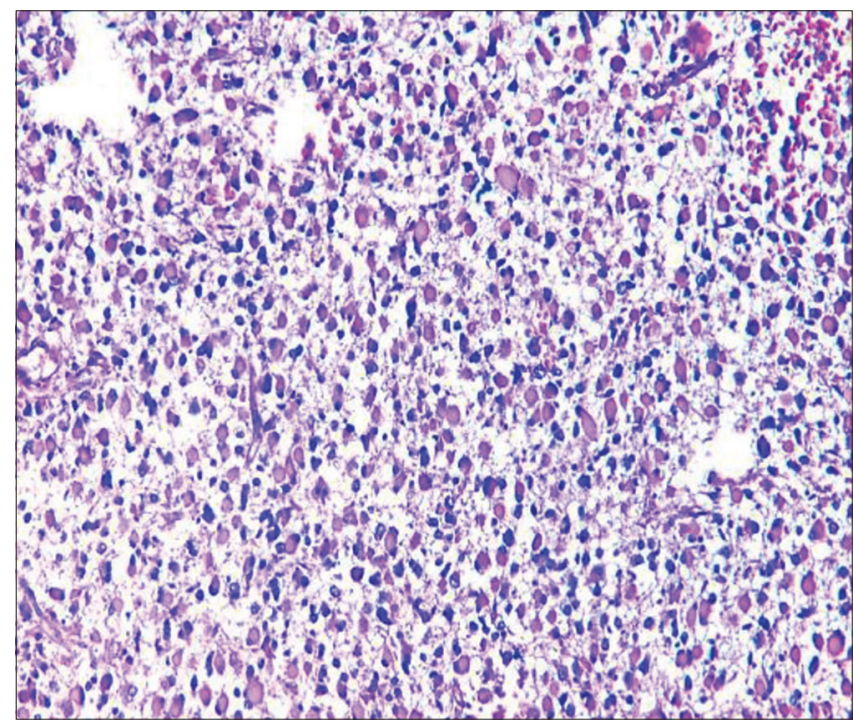

Figure 9: A case of diffuse gemistocytic astrocytoma, World Health Organization grade II, (hematoxylin and eosin $\times 100$ )

We find a left-sided preponderance in our study, as $34(56.7 \%)$ cases were left sided, $20(33.3 \%)$ cases were right sided and $6(10 \%)$ cases were midline in the location which are agreed with the results of Jonas et al., 2018 who showed $54.9 \%$ of the sample were left sided while $35.3 \%$ were right-sided cases [48].

As regards the clinical presentation among our studied cases; the most common clinical presenting symptom is seizures followed by headache agreed with Sánchez and Loddenkemper, 2017 [50]. We found in our study; $25(41.7 \%)$ cases presented with seizures, 


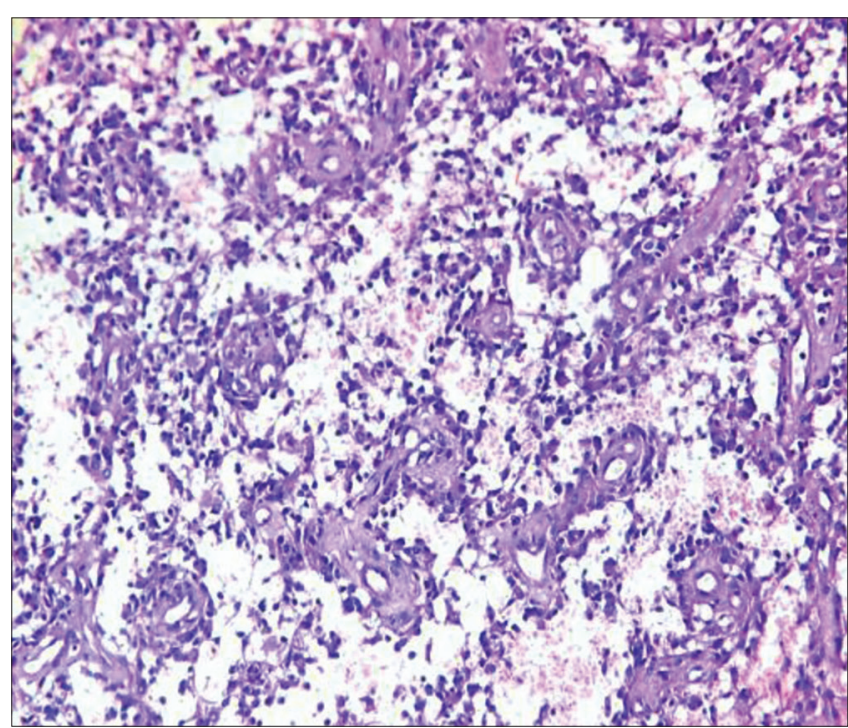

Figure 10: A case of pilomyxoid astrocytoma, World Health Organization grade II, showing angiocentric arrangement of the tumor cells with formation of pseudopapillary structures in a myxoid matrix (hematoxylin and eosin $\times 400$ )

$21(35 \%)$ cases presented with headache, 14 (23.3\%) cases are presented with hemiparesis. However, Rasmussen et al., 2017 and Dobran et al., 2018 results showed that focal neurological deficit was the most frequent presenting symptom mainly motor deficit, followed by hemianopsia and sensory symptoms. Seizures were the second most common presenting symptom [51], [52].

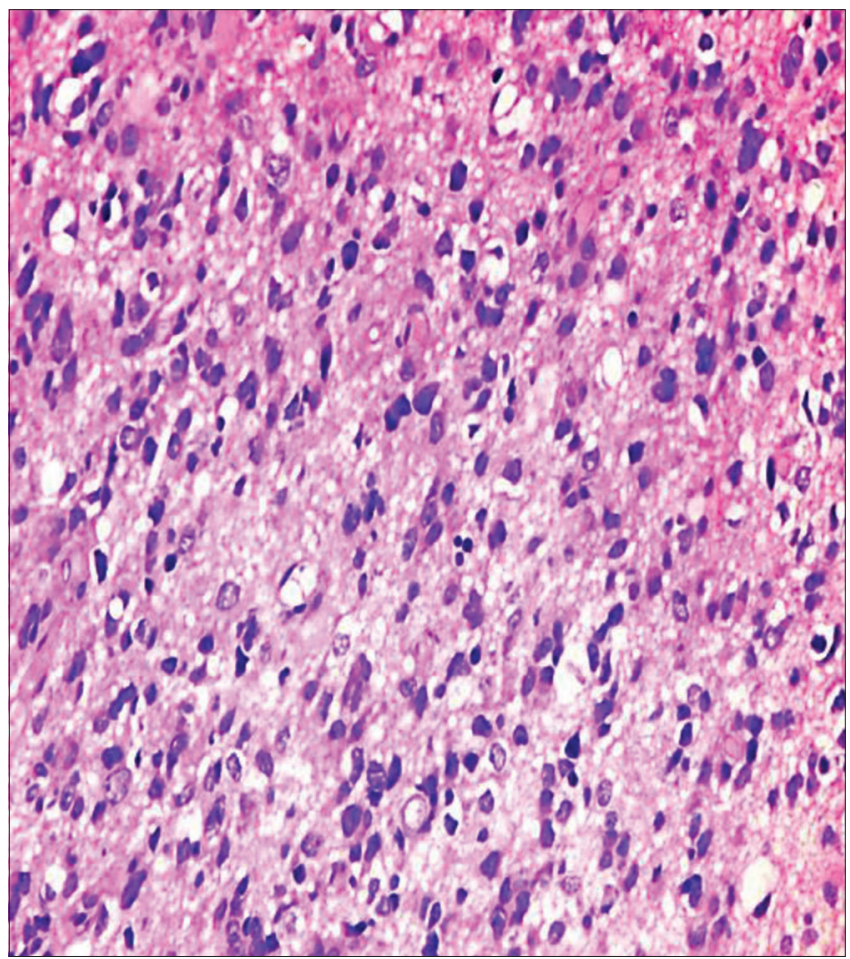

Figure 11: A case of anaplastic astrocytoma, World Health Organization grade III, showing extreme cellularity and marked pleomorphism (hematoxylin and eosin $\times 400$ )

Keogh and Henson, 2012 stated that clinical presentation of intracranial astrocytic tumors are usually variable and referable to the anatomic area

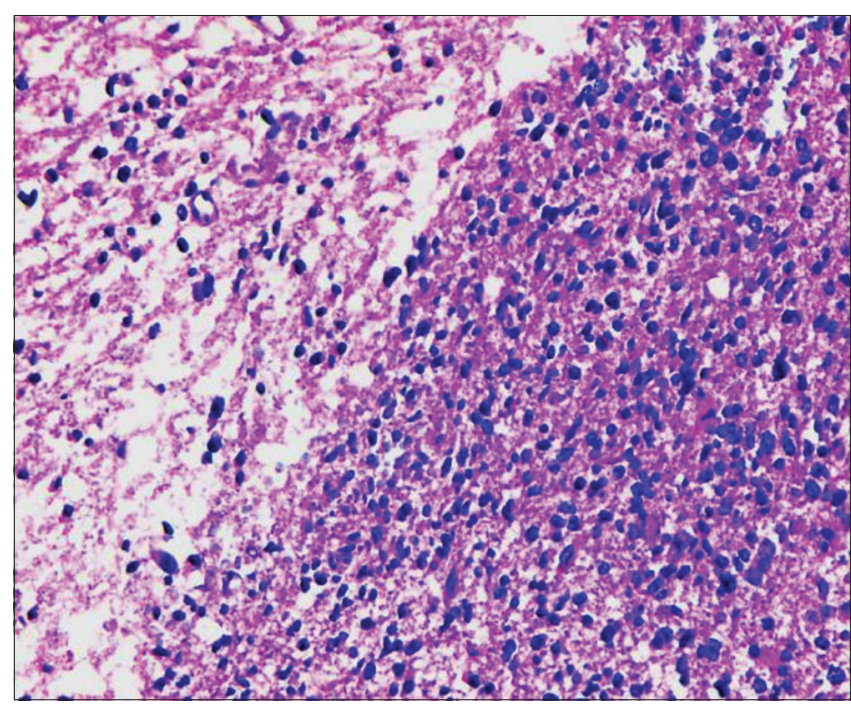

Figure 12: A case of recurrent astrocytic tumor diagnosed as anaplastic astrocytoma, World Health Organization grade III, showing extreme cellularity and marked pleomorphism (to the right). A component of mild cellularity and mild pleomorphism was seen (to the left) (hematoxylin and eosin $\times 400$ )

of the brain involved that sometimes may allow the tumor to reach substantial size while remaining clinically silent until present too late by hemiparesis. In contrast, small lesions in critical areas are more likely to clinically present too early by seizures [53]. Tumor recurrence were observed in six $(10 \%)$ cases in our study that agreed by Jinquan et al., 2016 who stated that recurrence and progression to higher grade lesions are key biological events and characteristic behaviors in the evolution process of gliomas especially astrocytic tumors [54].

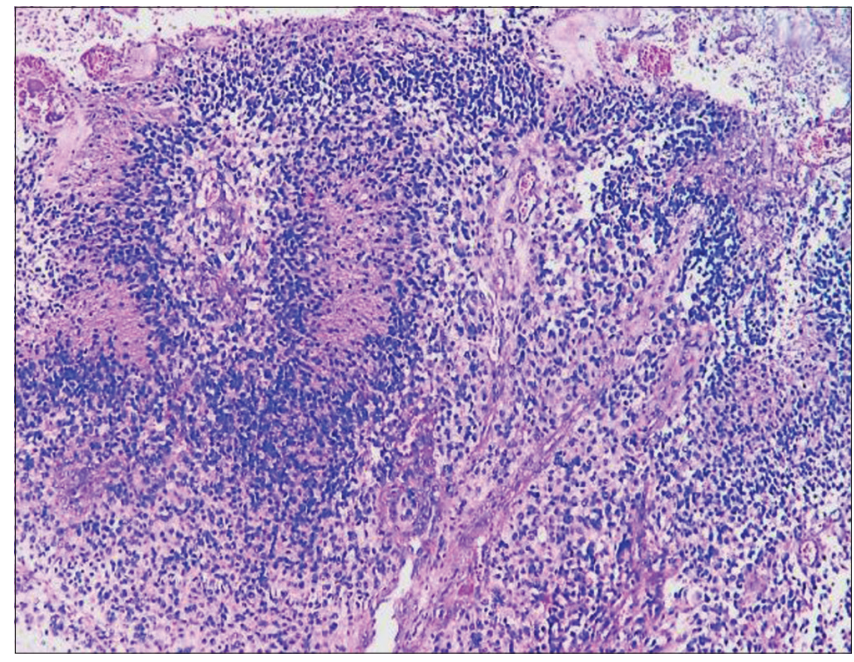

Figure 13: A case of glioblastoma, World Health Organization grade IV, showed endothelial vascular proliferations and palisaded necrosis (hematoxylin and eosin $\times 200$ )

In our study, we found six $(10 \%)$ cases of WHO grade I astrocytic tumors including five cases of pilocytic astrocytoma and one case of SEGA while fourteen $(23.3 \%)$ cases were classified as WHO grade II astrocytic tumors including $13(21.7 \%)$ cases were diffuse astrocytoma together with one (1.6\%) 


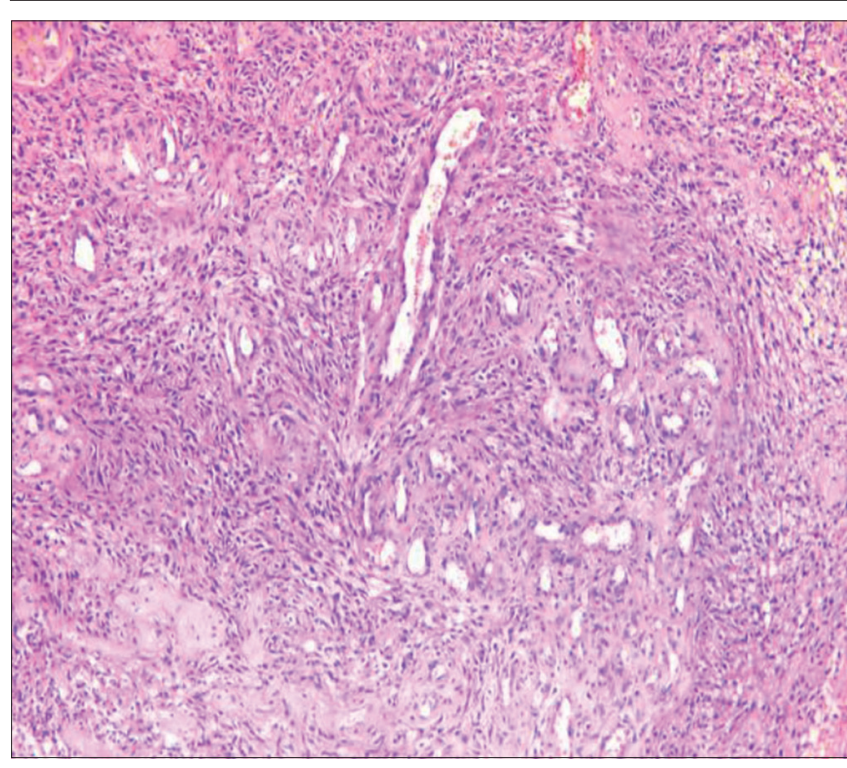

Figure 14: A case of glioblastoma, gliosarcoma variant, World Health Organization grade IV, showing extensive endothelial vascular proliferations (hematoxylin and eosin $\times 200$ )

case diagnosed as pilomyxoid astrocytoma which are similar to what is stated by Parvin and Fatemeh, 2019 whose results showed WHO grade I astrocytic tumors

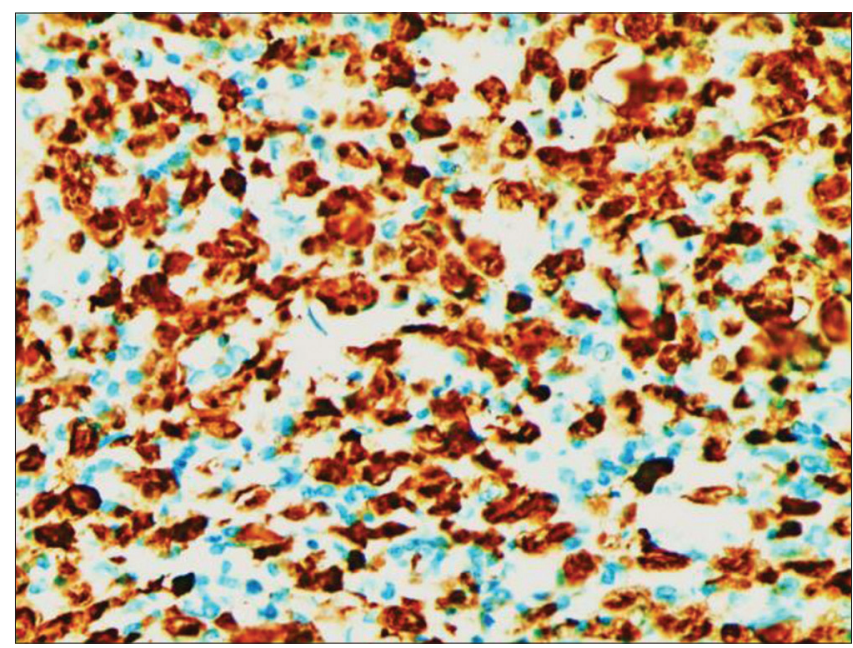

Figure 15: Strong diffuse ALK positivity in a case of anaplastic large cell lymphoma as a control (IHC ×400) are $10 \%$ while $\mathrm{WHO}$ grade II astrocytic tumors are $25 \%$ of their sample [46]. Chiba et al., 2017 revealed $37 \%$ of the cases were WHO grade II tumors [30].

Nine $(15 \%)$ cases were classified as anaplastic astrocytoma, WHO grade III, in our study that is agreed by Ann Mari et al., 2017 [55] while Chiba et al., 2017 revealed $25 \%$ of cases in their study were WHO grade III tumors [30] and higher than what is reported by Parvin and Fatemeh, 2019 who found it represents $5 \%$ of their sample [46].

The most common astrocytic tumor in our study was GBM as we have 31 cases classified as WHO grade IV astrocytic tumors, GBM, that is very close to what stated by Soomro et al., 2017 and Schneider et al., 2018 who found $50 \%$ of gliomas in adulthood are classified as GBM [56], [57] and our results not very far from what reported by Parvin and Fatemeh, 2019 who found that GBM is representing $60 \%$ of their studied astrocytic tumors [46]. A lower percentage was reported by Giedrius et al., 2019 who found it $36 \%$ of their sample while Chiba et al., 2017 found $37 \%$ of cases were WHO grade IV tumors [30].

Ostrom et al., 2018 stated that GBM was the most common astrocytic tumor that commonly present in the seventh decade with the median age at diagnosis of 65 years with male-to-female ratio; $1.6: 1$, accounting for $50-60 \%$ of all astrocytic tumors [58]. This data is matching to a great extend to what we concluded in our study as we find GBM was the most common astrocytic tumor commonly present in the seventh decade of life with median age at diagnosis of 54 years with a male-to-female ratio $2: 1$,accounting for $51.7 \%$ of all astrocytic tumors in our sample.

Correlation between age of patients and gender among our study group showed statistically significant correlation $(p=0.001)$ with females tending to present with astrocytic tumors at an older age than males but Robinson and Kleinschmidt, 2017 stated tumors affect older males than older females [59]. This is maybe due to possible genetic
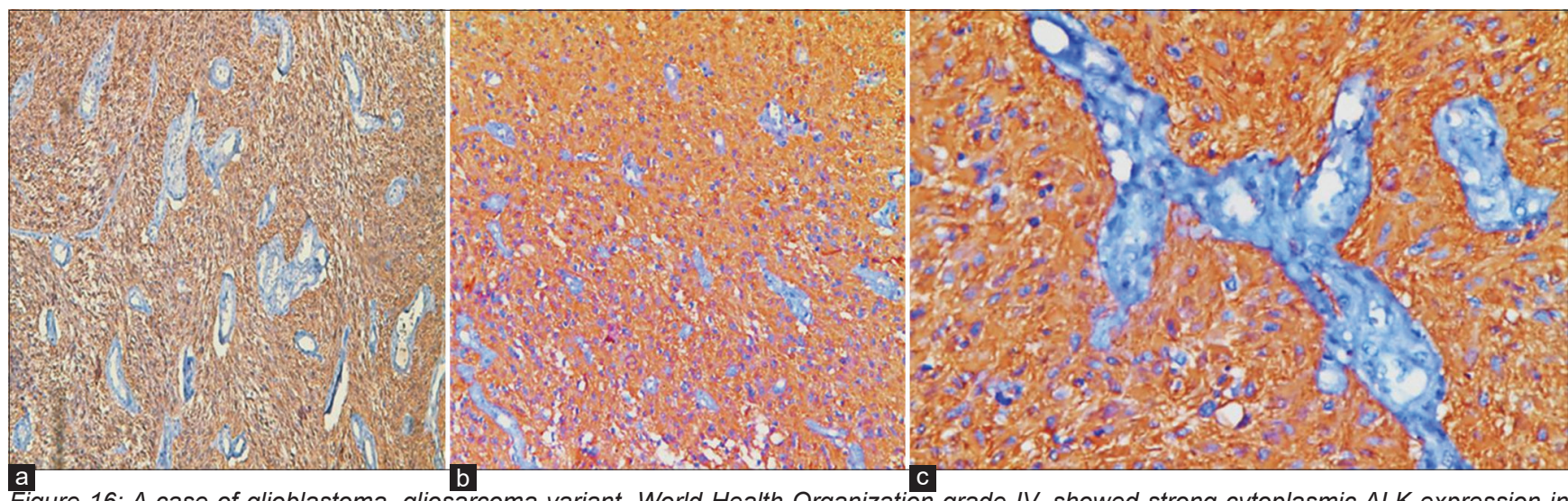

Figure 16: A case of glioblastoma, gliosarcoma variant, World Health Organization grade IV, showed strong cytoplasmic ALK expression in most of the tumor cells, score 4 (a); $(I H C \times 100),(b): \times 200,(c): \times 400$ 


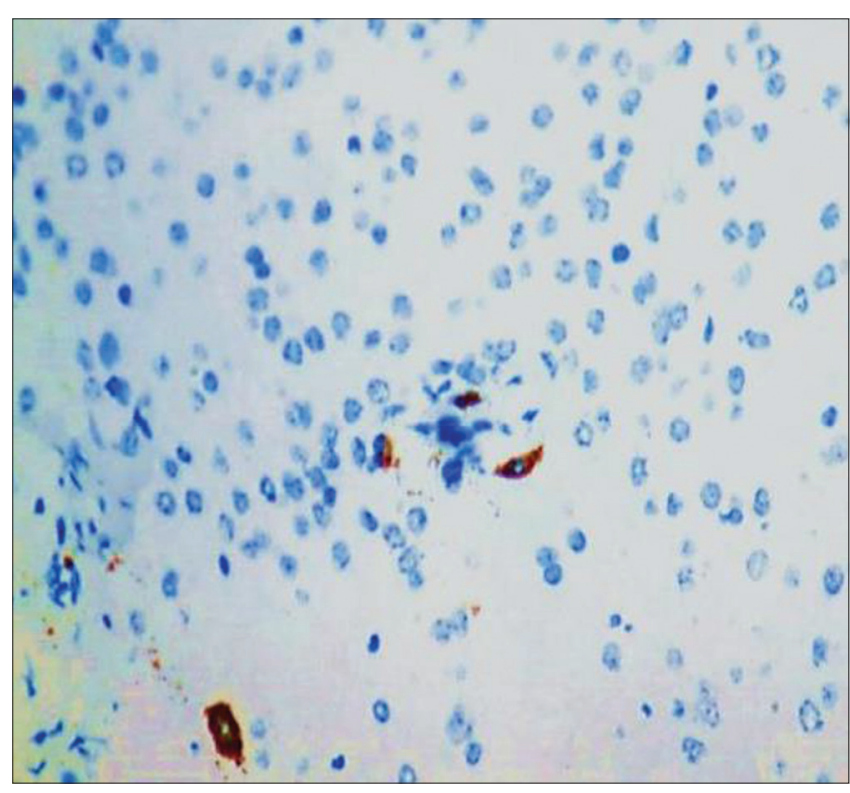

Figure 17: A case of anaplastic astrocytoma, World Health Organization grade III, showed strong cytoplasmic ALK expression in less than $25 \%$ of the tumor cells, score 1 (IHC x 400)

or environmental factors in addition to their large sample size (578 cases). Correlation between age of patients and WHO grade of the astrocytic tumors among our study group was statistically significant $(p=0.001)$ implying an increase in the WHO tumor grade with older age groups similar to what is stated by [51].

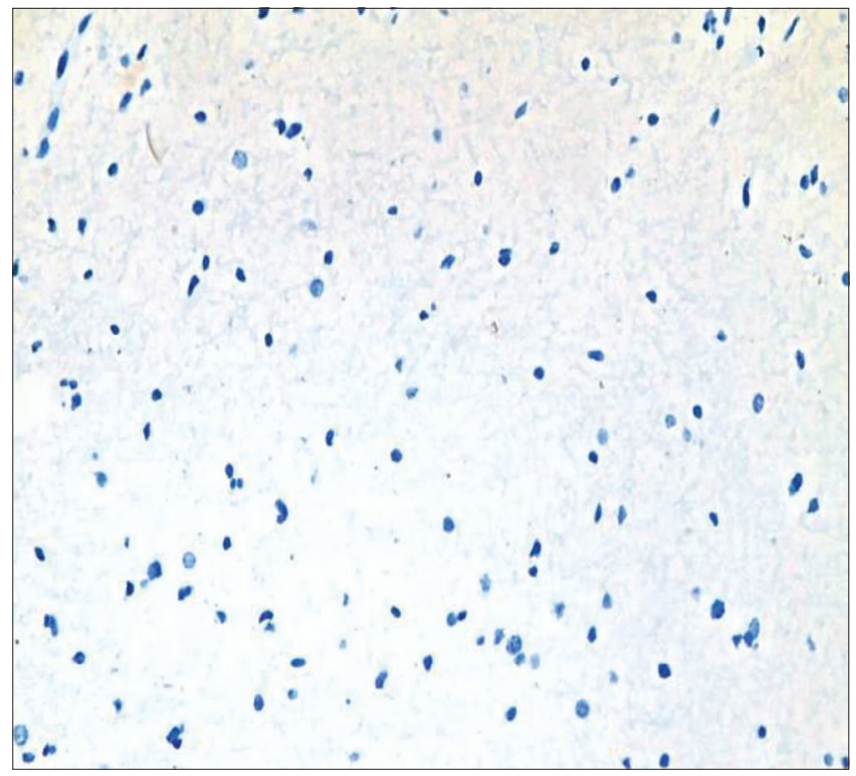

Figure 18: A case of pilocytic astrocytoma, World Health Organization I, showed negative ALK expression, score 0 (IHC x 400)

Furthermore, the correlation between the gender of patients with tumor location as well as tumor laterality was statistically significant $(p=0.0001$ and 0.001 , respectively) implying that tumor location tends to be more in the cerebellum, cerebrum, and cervical spine among males as well as the left-sided tumors are more common in males against what is reported by Elena et al., 2016 that found a nonsignificant correlation

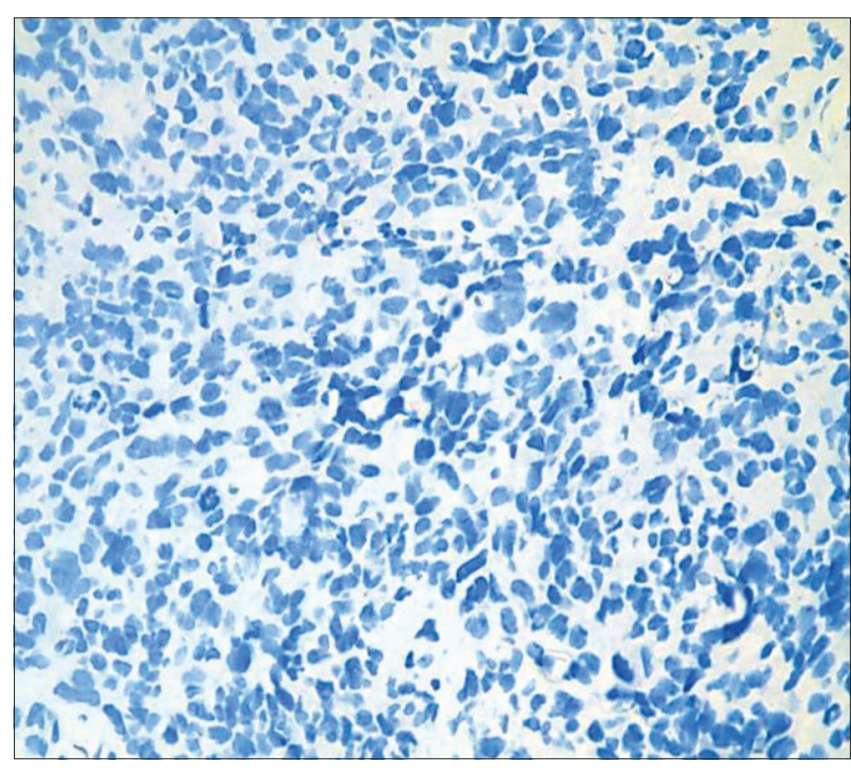

Figure 19: A case of glioblastoma, World Health Organization grade IV, showed negative ALK expression, score 0 (IHC x 400)

possibly due to large sample size that are conducted on one tumor type only; diffuse astrocytomas [60].

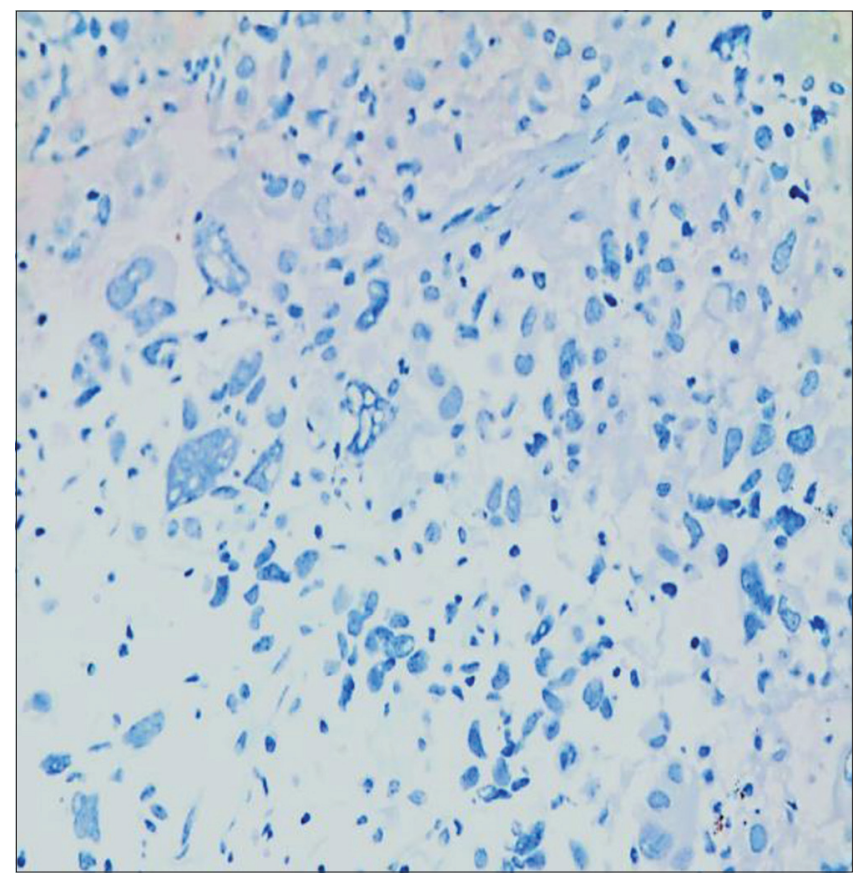

Figure 20: A case of glioblastoma, World Health Organization grade IV, showed negative ALK expression, score 0 (IHC x400)

Correlation between tumor recurrence and WHO grade as well as clinical presentation of the astrocytic tumors (Tables 1 and 2) was statistically significant ( $p=0.001$ and 0.003 , respectively) that signify recurrent cases will have a higher WHO grade that will be mostly presented by seizures as documented by Cai and Sughrue, 2018 who found WHO grade IV astrocytic tumors were following a previous low-grade astrocytic tumor [61].

Correlation between clinical presentation with tumor location and WHO grade of astrocytic tumors was statistically significant in our study $(p=0.006$ and 
Table 1: Relationship between ALK and clinicopathological variables

\begin{tabular}{|c|c|c|c|c|}
\hline \multirow[t]{2}{*}{ Factors } & \multicolumn{2}{|l|}{ ALK expression } & \multirow[t]{2}{*}{$\mathrm{p}$-value } & \multirow[t]{2}{*}{ Significance } \\
\hline & Negative $\mathrm{n}=57$ & Positive $\mathrm{n}=3$ & & \\
\hline Age (years) Mean $\pm S D$ & $42.75 \pm 15.9$ & $48.67 \pm 7.09$ & 0.528 & Insignificant \\
\hline \multicolumn{5}{|l|}{ Sex } \\
\hline Male & 39 & 1 & \multirow[t]{2}{*}{0.209} & \multirow[t]{2}{*}{ Insignificant } \\
\hline Female & 18 & 2 & & \\
\hline \multicolumn{5}{|l|}{ Laterality } \\
\hline Right & 19 & 1 & \multirow[t]{3}{*}{0.830} & \multirow[t]{3}{*}{ Insignificant } \\
\hline Left & 32 & 2 & & \\
\hline Midline & 6 & 0 & & \\
\hline \multicolumn{5}{|l|}{ Tumor location } \\
\hline Occipital & 2 & 1 & \multirow[t]{7}{*}{0.394} & \multirow[t]{7}{*}{ Insignificant } \\
\hline Parietal & 20 & 1 & & \\
\hline Frontal & 9 & 0 & & \\
\hline Temporal & 14 & 1 & & \\
\hline Spinal & 2 & 0 & & \\
\hline Brain stem & 4 & 0 & & \\
\hline Cerebellum & 6 & 0 & & \\
\hline \multicolumn{5}{|l|}{ Histological types } \\
\hline Pilocytic & 5 & 0 & \multirow[t]{6}{*}{0.863} & \multirow[t]{6}{*}{ Insignificant } \\
\hline Pilomyxoid & 1 & 0 & & \\
\hline Diffuse & 13 & 0 & & \\
\hline Anaplastic & 8 & 1 & & \\
\hline GBM & 29 & 2 & & \\
\hline SEGA & 1 & 0 & & \\
\hline \multicolumn{5}{|l|}{ Recurrence } \\
\hline Yes & 6 & 0 & \multirow[t]{2}{*}{0.554} & \multirow[t]{2}{*}{ Insignificant } \\
\hline No & 51 & 3 & & \\
\hline \multicolumn{5}{|l|}{ WHO } \\
\hline $\mathrm{G} 1$ & 6 & 0 & \multirow[t]{4}{*}{0.594} & \multirow[t]{4}{*}{ Insignificant } \\
\hline GII & 14 & 0 & & \\
\hline GIII & 8 & 1 & & \\
\hline GVI & 29 & 2 & & \\
\hline \multicolumn{5}{|l|}{ Clinical picture } \\
\hline Seizures & 24 & 1 & \multirow[t]{3}{*}{0.157} & \multirow[t]{3}{*}{ Insignificant } \\
\hline Headache & 21 & 0 & & \\
\hline Hemiparesis & 12 & 2 & & \\
\hline
\end{tabular}

0.001 respectively). Tumors that affect brain stem and cervical spine are presented by hemiparesis while tumors that are affect the cerebral hemisphere are commonly presented with seizures and cerebellar tumors are commonly presented with headache. Correlation between tumor laterality on one hand and tumor location as well as the clinical presentation of astrocytic tumors among our study group, on the other hand, was statistically significant $(p=0.001)$

Table 2: Relationship between WHO grade and clinicopathological variables

\begin{tabular}{|c|c|c|c|c|c|c|}
\hline \multirow[t]{2}{*}{ Factors } & \multicolumn{4}{|l|}{ WHO grade } & \multirow[t]{2}{*}{$p$-value } & \multirow[t]{2}{*}{ Significance } \\
\hline & $\mathrm{GI} n=6$ & $\mathrm{G} \| \mathrm{n}=14$ & GIII $n=9$ & GIV $n=31$ & & \\
\hline Age (years) & $19.3 \pm 5.24$ & $30.64 \pm 8.6$ & $40.56 \pm 6.76$ & $53.97 \pm 11.1$ & 0.000 & Significant \\
\hline \multicolumn{7}{|l|}{ Mean \pm SD } \\
\hline \multicolumn{7}{|l|}{ Sex } \\
\hline Male & 3 & 4 & 5 & 28 & 0.000 & Significant \\
\hline Female & 3 & 10 & 4 & 3 & & \\
\hline \multicolumn{7}{|l|}{ Laterality } \\
\hline Right & 0 & 7 & 3 & 10 & 0.001 & Significant \\
\hline Left & 6 & 3 & 4 & 21 & & \\
\hline Midline & 0 & 4 & 2 & 0 & & \\
\hline \multirow{2}{*}{\multicolumn{7}{|c|}{$\begin{array}{l}\text { Tumor } \\
\text { location }\end{array}$}} \\
\hline & & & & & & \\
\hline Occipital & 0 & 0 & 1 & 2 & 0.001 & Significant \\
\hline Parietal & 1 & 6 & 3 & 11 & & \\
\hline Frontal & 0 & 2 & 2 & 5 & & \\
\hline Temporal & 1 & 2 & 1 & 11 & & \\
\hline Spinal & 0 & 2 & 0 & 0 & & \\
\hline Brain stem & 0 & 2 & 2 & 0 & & \\
\hline Cerebellum & 4 & 0 & 0 & 2 & & \\
\hline \multicolumn{7}{|l|}{ Recurrence } \\
\hline Yes & 0 & 1 & 1 & 4 & 0.778 & Insignifican \\
\hline No & 6 & 13 & 8 & 27 & & \\
\hline \multicolumn{7}{|l|}{ Clinical picture } \\
\hline Seizures & 3 & 7 & 4 & 11 & 0.601 & Insignifican \\
\hline Headache & 3 & 3 & 2 & 13 & & \\
\hline Hemiparesis & 0 & 4 & 3 & 7 & & \\
\hline
\end{tabular}

implying all midline cases are having brain stem and cervical spine locations presented by hemiparesis. Left-sided tumors are mostly having cerebellar and parieto-temporal locations while right sided tumors are commonly affecting the frontal lobe. Both left and rightsided tumors are commonly presented by seizures followed by headache.

There is also a significant relationship between tumor laterality and WHO grade of the astrocytic tumors among our study group $(p=0.001)$ implying the more the left and right-sided tumors with the higher the WHO grade. Tumor laterality and tumor locations must be taken in our considerations as advised by Salo et al., 2002 who stated that tumor laterality and tumor location among cases with brain tumor can affect the quality of life evidenced by brain tumors that located in the right hemisphere seemed to have a poorer quality of life than left-sided tumors based on regular postoperative follow-up [62].

As for a correlation between tumor location and WHO grade of the astrocytic tumors among the study group was statistically significant $(p=0.001)$. WHO grade I tumors were commonly located in the cerebellum that agreed by Bornhorst et al., 2016 who stated that pilocytic astrocytoma, the most common pediatric brain tumor, is most commonly located in the cerebellum [63]. WHO grade II and WHO grade III tumors were commonly located in the parietal lobe, while WHO grade IV tumors were commonly located in the parieto-temporal region identical to results of Dobran et al., 2018 [52], however, results of Zalata et al., 2011 and Ze-Lin Sun et al., 2015 stated that frontal lobe is the most common location [9], [49].

\section{Conclusions}

GBM and gliosarcoma are highly aggressive tumors. Recent advances in molecular and pathological diagnosis have a great impact on the prediction of prognosis and recurrence. Expression of ALK was found to be abundant among high-grade like anaplastic large cell lymphoma and some aggressive cases of NSCLC and they benefit greatly from targeted ALK chemotherapeutics. In a similar approach, more studies and experiments should also be attempted on highgrade astrocytic tumors. In this study, three positive cases were seen in higher grade astrocytic tumors, particularly gliosarcoma. Therefore, larger studies on a wider scale of GBM patients especially gliosarcoma variant are needed to elucidate the exact role of ALK in this high-grade astrocytic tumor as so far most studied concluded no significant role. Other markers are recommended to be used in association with ALK in such studies on GBM to improve test sensitivity like EGFR, Cyclin D1, ROS, PTEN and cMET. Molecular studies may be used in combination with immunohistochemical studies to overcome the effect of the underexpression of ALK protein in tumors that have ALK gene mutations. 


\section{References}

1. Ostrom QT, Gittleman H, Fulop J, Liu M, Blanda R, Kromer C, et al. Primary brain and central nervous system tumors diagnosed in the United States in 2008-2012. Neuro Oncol. 2015;17 Suppl 4:iv1-62. https://doi.org/10.1093/neuonc/nov189 PMid:26511214

2. Louis DN, Ohgaki H, Wiestler OD, Cavenee WK, Burger PC, Jouvet A, Scheithauer BW, Kleihues P. The 2007 WHO classification of tumors of the CNS. Acta Neuropathol. 2007;114(2):97-109. https://doi.org/10.1007/s00401-007-0243-4 PMid: 17618441

3. Reifenberger G, Perry A, Louis DN. The 2016 World Health Organization classification of tumors of the central nervous system: A summary. Acta Neuropathol. 2016;131(6):803-20. https://doi.org/10.1007/s00401-016-1545-1

PMid:27157931

4. Wrensch M, Minn Y, Chew T. Epidemiology of primary brain tumors: Current concepts and review of the literature. Neuro Oncol. 2002;4(4):278-99. https://doi.org/10.1093/ neuonc/4.4.278

PMid: 12356358

5. Hardell L, Carlberg M. Mobile phone and cordless phone use and risk for glioma-analysis of pooled case-control studies in Sweden, 1997-2003 and 2007-2009. Pathophysiology. 2015;22(1):1-13. https://doi.org/10.1016/j.pathophys.2014.10.001

PMid:25466607

6. Ostrom QT, Bauchet L, Davis F, Deltour I, Eastman C, Fisher JL, et al. The epidemiology of glioma in adults: A "state of the science" review. Neurooncology. 2014;16(7):896-913. https:// doi.org/10.1093/neuonc/nou087

PMid:24842956

7. Kitange GJ, Templeton KL, Jenkins RB. Recent advances in the molecular genetics of primary gliomas. Opin Oncol. 2003;15(3):197-203. https://doi. org/10.1097/00001622-200305000-00003

\section{PMid:12778011}

8. Globocan. Cancer Incidence and Mortality Worldwide: IARC Cancer-base No. 11. (Database on the Internet). Lyon, France: International Agency for Research on Cancer; 2013. Available from: http://www.globocan.iarc.fr [Last accessed on 2016 Jun 14].

9. Zalata KR, El-Tantawy DA, Abdel-Aziz A, Ibraheim AW, Halaka $\mathrm{AH}$, Gawish $\mathrm{HH}$, et al. Frequency of central nervous system tumors in Delta region. Indian J Pathol Microbiol. 2011;54(2):299-306. https://doi.org/10.4103/0377-4929.81607 PMid:21623078

10. Mokhtar N, Salama A, Badawy O, Khorshed E, Mohamed G, Ibrahim M, et al. Cancer Pathology Profile 2000-2011 United States: NCl; 2011.

11. Louis DN, Ohgaki H, Wiestler OD, Cavenee WK. World Health Organization Histological Classification of Tumours of the Central Nervous System. France: International Agency for Research on Cancer.

12. Forbes JA, Mobley BC, O'Lynnger TM, Cooper CM, Ghiassi M, Hanif R, et al. Pediatric cerebellar pilomyxoid-spectrum astrocytomas. J Neurosurg Pediatr. 2011;8(1):90-6. https://doi. org/10.3171/2011.4.PEDS1115 PMid:21721894

13. Wirsching HG, Galanis E, Weller M. Glioblastoma. Handb Clin Neurol. 2016;134:381-97. https://doi.org/10.1016/ B978-0-12-802997-8.000232 PMid:26948367
14. Burzynski SR. Treatments for astrocytic tumors in children. Paediatr Drugs. 2006;8(3):167-78. https://doi. org/10.2165/00148581-200608030-00003

PMid: 16774296

15. Kleihues P, Burger PC, Rosenblum MK, Paulus W, Scheithauer BW. WHO Classification of Tumours: Pathology and Genetics of Tumours of the Nervous System. Lyon: IARC Press;2007. p. 30-2.

16. Choi SH, Kim JW, Chang JS, Cho JH, Kim SH, Chang JH, et al. Impact of including peritumoral edema in radiotherapy target volume on patterns of failure in glioblastoma following temozolomide-based chemoradiotherapy. Sci Rep. 2017;7:42148. https://doi.org/10.1038/srep42148 PMid:28176884

17. Furnari FB, Fenton T, Bachoo RM. Malignant astrocytic glioma: Genetics, biology, and treatment. Genes Dev. 2007;21(21):2683710. https://doi.org/10.1101/gad.1596707 PMid: 17974913

18. Perme MP, Stare J, Estève J. On estimation in relative survival. Biometrics. 2012;68(1):113-20. https://doi. org/10.1111/j.1541-0420.2011.01640.x PMid:21689081

19. Kennedy B. Astrocytoma; 2016. Available from: http:// www.emedicine.medscape.com/article/283453 [Last accessed on 2021 Oct 30].

20. Garcia CR, Slone SA, Dolecek TA, Huang B, Neltner JH, Villano JL. Primary central nervous system tumor treatment and survival in the United States, 2004-2015. J Neurooncol. 2019;144(1):179-91. https://doi.org/10.1007/ s11060-019-03218-8

PMid:31254264

21. Morris SW, Kirstein MN, Valentine MB. Fusion of a kinase gene, ALK, to a nucleolar protein gene, NPM, in non-Hodgkin's lymphoma. Science. 1994;263(5151):1281-4. https://doi. org/10.1126/science. 8122112

PMid:8122112

22. Yao $S$, Cheng $M$, Zhang $Q$, Wasik $M$, Kelsh $R$, Winkler $C$. Anaplastic lymphoma kinase is required for neurogenesis in the developing central nervous system of zebrafish. PLoS One. 2013;8(5):e63757. https://doi.org/10.1371/journal. pone. 0063757 PMid:23667670

23. Fujimoto J, Shiota M, Iwahara T, Seki N, Satoh H, Mori S, et al. Characterization of the transforming activity of p80, a hyperphosphorylated protein in a Ki-1 lymphoma cell line with chromosomal translocation $\mathrm{t}(2 ; 5)$. Proc Natl Acad Sci USA. 1996;93(9):4181-6. https://doi.org/10.1073/pnas.93.9.4181 PMid:8633037

24. Wang D, Li D, Qin G, Zhang W, Ouyang J, Zhang M, et al. The structural characterization of tumor fusion genes and proteins. Comput Math Methods Med. 2015;2015:912742. https://doi. org/10.1155/2015/912742

PMid:26347798

25. Dejean E, Renalier MH, Foisseau M, Agirre X, Joseph N, de Paiva GR. Hypoxia-microRNA-16 downregulation induces VEGF expression in anaplastic lymphoma kinase (ALK)-positive anaplastic large-cell lymphomas. Leukemia. 2011;25(12):188290. https://doi.org/10.1038/leu.2011.168 PMid:21778999

26. Wiesner T, Lee W, Obenauf A, Ran L, Murali R, Zhang Q, et al Alternative transcription initiation leads to expression of novel ALK isoform in cancer. Nature. 2015;526(7573):453-7. https:// doi.org/10.1038/nature1525 PMid:26444240

27. Couts KL, Bemis J, Turner JA, Bagby SM, Murphy D, 
Christiansen $\mathrm{J}$, et al. ALK inhibitor response in melanomas expressing EML4-ALK fusions and alternate ALK isoforms. Mol Cancer Ther. 2018;17(1):222-31. https://doi.org/10.1158/15357163.MCT-17-0472

PMid:29054983

28. Aghajan Y, Levy ML, Malicki DM, Crawford JR. Novel PPP1CBALK fusion protein in a high-grade glioma of infancy. BMJ Case Rep. 2016;2016:bcr2016217189. https://doi.org/10.1136/ bcr-2016-217189 PMid:27530886

29. Grob T, Heilenkotter U, Geist S, Paluchowski P, Wilke C, Jaenicke $F$. Rare oncogenic mutations of predictive markers for targeted therapy in triple-negative breast cancer. Breast Cancer Res Treat. 2012;134(2):561-7. https://doi.org/10.1007/ s10549-012-2092-7 PMid:22610646

30. Chiba R, Akiya M, Hashimura M, Oguri $Y$, Inukai M, Hara A, et al. ALK signaling cascade confers multiple advantages to glioblastoma cells through neovascularization and cell proliferation. PLoS One. 2017;12(8):e0183516. https://doi. org/10.1371/journal.pone. 0183516

PMid:28837676

31. Ricci-Vitiani L, Pallini R, Biffoni M, Todaro M, Invernici G, Cenci T, et al. Tumour vascularization via endothelial differentiation of glioblastoma stem-like cells. Nature. 2010;468(7325):824-8. https://doi.org/10.1038/nature09557

PMid:21102434

32. Marzec M, Liu X, Wong W, Yang Y, Pasha T, Kantekure K. Oncogenic kinase NPM/ALK induces expression of HIF-1 $\alpha$ mRNA. Oncogene. 2011;30(11):1372-8. https://doi.org/10.1038/ onc. 2010.505

PMid:21102525

33. Wellstein A. ALK receptor activation, ligands and therapeutic targeting in glioblastoma and in other cancers. Front Oncol. 2012;2:192. https://doi.org/10.3389/fonc.2012.00192 PMid:23267434

34. Anne-Florence B, Graham M, Ramkissoon S, Ramkissoon L, Pelton $\mathrm{K}$, Pages $\mathrm{M}$, et al. Ampifications and rearrangements are recognizable targets in glioblastoma. Neurooncology. 2018;20 Suppl 6:vi204-5. https://doi.org/10.1093/neuonc/ noy 148.848

35. Powers C, Aigner A, Stoica GE, McDonnell K, Wellstein A. Pleiotrophin signaling through anaplastic lymphoma kinase is rate-limiting for glioblastoma growth. J Biol Chem. 2002;277(16):14153-8. https://doi.org/10.1074/jbc.M112354200 PMid:11809760

36. Grzelinski M, Steinberg F, Martens T, Czubayko F, Lamszus K, Aigner A. Enhanced antitumorigenic effects in glioblastoma on double targeting of pleiotrophin and its receptor ALK. Neoplasia. 2009;11(2):145-56. https://doi.org/10.1593/neo.81040 PMid:19177199

37. Hudson L, Kulig K, Young D, McLendon R, Abernet A. ALK and CMET expression in glioblastoma multiforme: Implications for therapeutic targeting. Mol Cancer Ther. 2011;10 Suppl 1:A42. https://doi.org/10.1158/1535-7163.TARG-11-A42

38. Wallace GC, Dixon-Mah YN, Vandergrift WA, Ray SK, Haar CP, Mittendorf AM, et al. Targeting oncogenic ALK and MET in glioblastoma. Metab Brain Dis. 2013;28(3):355-66. https://doi. org/10.1007/s11011-013-9401-7 PMid:23543207

39. Morana G, Tortora D, Staglianò S, Nozza P, Mascelli S, Severino M, et al. Pediatric astrocytic tumor grading: Comparison between arterial spin labeling and dynamic susceptibility contrast MRI perfusion. Neuroradiology. 2018;60(4):437-46. https://doi.org/10.1007/s00234-018-1992-6

\section{PMid:29453753}

40. Zhang L, Kundu S, Feenstra T, Li X, Jin C, Laaniste L, et al Pleiotrophin promotes vascular abnormalization in gliomas correlates with poor survival in astrocytomas. Sci Signal. 2015;8(406):ra125. https://doi.org/10.1126/scisignal.aaa1690 PMid:26645582

41. Karagkounis G, Stranjalis G, Argyrakos T, Pantelaion V, Mastoris K, Rontogianni D, et al. Anaplastic lymphoma kinase expression and gene alterations in glioblastoma: Correlations with clinical outcome. J Clin Pathol. 2017;70(7):593-9. https:// doi.org/10.1136/jclinpath-2016-204102 PMid:27993946

42. Bu L, Hameed NU, Luo C, Hong P, Zhou X, Wang S, et al. Germline ALK Variations are associated with a poor prognosis in glioma and IDH-wildtype glioblastoma. J Neurooncol. 2021;152(1):2736. https://doi.org/10.1007/s11060-020-03676-5 PMid:33486679

43. Junca A. Villalva C, Tachon G, Rivet P, Cortes U, Guilloteau K, et al. Crizotinib targets in glioblastoma stem cells. Cancer Med. 2017;6(11):2625-34. https://doi.org/10.1002/cam4.1167 PMid:28960893

44. Schäfer N, Gielen GH, Rauschenbach L, Kebir S, Till A, Reinartz $\mathrm{R}$, et al. Longitudinal heterogeneity in glioblastoma: Moving targets in recurrent versus primary tumors. J Transl Med. 2019;17(1):96. https://doi.org/10.1186/s12967-019-1846-y PMid:30894200

45. Chmielecki J, Bailey M, He J, Elvin J, Vergilio JA, Ramkissoon S, et al. Genomic profiling of a large set of diverse pediatric cancers identifies known and novel mutations across tumor spectra. Cancer Res. 2017;77(2):509-19. https://doi.org/10.1158/00085472.CAN-16-1106 PMid:28069802

46. Mahzouni P, Taheri F. An immunohistochemical study of cyclin D1 expression in astrocytic tumors and its correlation with tumor grade. Iran J Pathol. 2019;14(3):252-7. https://doi.org/10.30699/ ijp.2019.82024.1771

PMid:31583003

47. Raverot G, Wierinckx A, Dantony E, Auger C, Chapas G, Villeneuve $\mathrm{L}$, et al. Prognostic factors in prolactin pituitary tumors: Clinical, histological, and molecular data from a series of 94 patients with a long postoperative follow-up. J Clin Endocrinol Metab. 2010;95(4):1708-16. https://doi.org/10.1210/ jc.2009-1191

PMid:20164287

48. Feldheim J, Kessler AF, Schmitt D, Wilczek L, Linsenmann T, Dahlmann $\mathrm{M}$, et al. Expression of activating transcription factor 5 (ATF5) is increased in astrocytomas of different WHO grades and correlates with survival of glioblastoma patients. Onco Targets Ther. 2018;11:8673-84. https://doi.org/10.2147/OTT. S176549

PMid:30584325

49. Sun ZL, Chan AK, Chen LC, Tang C, Zhang ZY, Ding XJ, et al. TERT promoter mutated WHO grades II and III gliomas are located preferentially in the frontal lobe and avoid the midline. Int J Clin Exp Pathol. 2015;8(9):11485-94. PMid:26617880

50. Sánchez IV, Loddenkemper T. Seizures caused by brain tumors in children. Seizure. 2017;44:98-107. https://doi.org/10.1016/j. seizure.2016.11.028 PMid:28017579

51. Rasmussen BK, Hansen S, Laursen RJ, Kosteljanetz $M$, Schultz H, Nørgård BM, et al. Epidemiology, clinical characteristics, symptoms and predictors of glioma patients grade I-IV in Danish neuro-oncology registry. J Neurooncol. 2017;135(3):571-9. https://doi.org/10.1007/s11060-017-2607-5 


\section{PMid:28861666}

52. Dobran M, Nasi D, Chiriatti S, Gladi M, Somma LD, lacoangeli $\mathrm{M}$, et al. Prognostic factors in glioblastoma: Is there a role for epilepsy. Neurol Med Chir (Tokyo). 2018;58(3):110-5. https://doi.org/10.2176/nmc.0a.2017-0167

PMid:29343677

53. Keogh BP, Henson JW. Clinical manifestations and diagnostic imaging of brain tumors. Hematol Oncol Clin North Am. 2012;26(4):733-55. https://doi.org/10.1016/j.hoc.2012.05.002 PMid:22794281

54. Cai J, Zhang C, Zhang W, Wang G, Yao K, Wang Z, et al. ATRX, IDH1-R132H and Ki-67 immunohistochemistry as a classification scheme for astrocytic tumors. Oncoscience. 2016;3(7-8):258-65. https://doi.org/10.18632/oncoscience.317 PMid:27713914

55. Rosager AM, Sørensen MD, Dahlrot $\mathrm{RH}$, Hansen $\mathrm{S}$, Schonberg DL, Rich JN, et al. Transferrin receptor-1 and ferritin heavy and light chains in astrocytic brain tumors: Expression and prognostic value. PLoS One. 2017;12(8):e0182954. https:// doi.org/10.1371/journal.pone.0182954

PMid:28837569

56. Soomro SH, Ting LR, Qing YY, Ren M. Molecular biology of glioblastoma: Classification and mutational locations. J Pak Med Assoc. 2017;67(9):1410-4.

PMid:28924284

57. Schneider T, Mawrin C, Scherlach C, Skalej M, Firsching R. Gliomas in adults. Dtsch Arztebl Int. 2010;107(45):799-807; quiz 808. https://doi.org/10.3238/arztebl.2010.0799

PMid:21124703
58. Ostrom QT, Gittleman H, Truitt G, Boscia A, Kruchko, A CBTRUS statistical report: Primary brain and other central nervous system tumors diagnosed in the United States in 2011-2015. Neuro Oncol. 2018;20 Suppl 4:iv1-iv86. https://doi. org/10.1093/neuonc/noy131

PMid:30445539

59. Robinson $\mathrm{C}$, Kleinschmidt $\mathrm{BK}$. IDH1-mutation in diffuse gliomas in persons age 55 years and over. J Neuropathol Exp Neurol. 2017;76(2):151-4. https://doi.org/10.1093/jnen/nlw112

PMid:28110298

60. Martínez-Sáez E, Peg V, Ortega-Aznar A, Martínez-Ricarte F, Camacho J, Hernández-Losa J, et al. pelF4E as an independent prognostic factor and a potential therapeutic target in diffuse infiltrating astrocytomas. Cancer Med. 2016;5(9):2501-12. https://doi.org/10.1002/cam4.817

PMid:27440383

61. Cai X, Sughrue ME. Glioblastoma: New therapeutic strategies to address cellular and genomic complexity. Oncotarget. 2018;9(10):9540-54. https://doi.org/10.18632/oncotarget.23476 PMid:29507709

62. Salo A, Niemela M Joukamaa and J Koivukangas. Effect of brain tumour laterality on patients' perceived quality of life. J Neurol Neurosurg Psychiatry. 2002;72(3):373-7. https://doi. org/10.1136/jnnp.72.3.373

PMid:11861699

63. Bornhorst M, Frappaz D, Packer RJ. Pilocytic astrocytomas. Handb Clin Neurol. 2016;134:329-44. https://doi.org/10.1016/ B978-0-12-802997-8.00020-7

PMid:26948364 